\title{
HYDROLYSIS OF SUCROSE BY IMMOBILIZED Saccharomyces cerevisiae INVERTASE
}

Waleed A. Mahmood

\author{
Food Sci. Dept., College of Agric. and Forestry, Mosul Univ. Iraq
}

\begin{abstract}
Invertase from Saccharomyces cerevisiae was immobilized by entrapment in carrageenan gel beads and used for sucrose hydrolysis. The immobilization efficiency was $88 \%$ when the concentration of the added enzyme was $100 \mathrm{unit} / \mathrm{ml}$ of gel and dropped to $49 \%$ upon increasing the added enzyme concentration to 500 $\mathrm{U} / \mathrm{ml}$. The immobilized enzyme remained fully active after 12 weeks of storage at $4^{\circ} \mathrm{C}$. The hydrolytic activity of the enzyme was found to be influenced by temperature and $\mathrm{pH}$. The preferred hydrolysis temperature was $55{ }^{\circ} \mathrm{C}$ for both the free and immobilized forms. The optimum $\mathrm{pH}$ was 4.5 for the free enzyme and was $4.5-5.5$ for the immobilized enzyme. $\mathrm{K}_{\mathrm{m}}$ values for the free and immobilized invertase were 63.4 and $87.8 \mathrm{mM}$, respectively. $\mathrm{V}_{\max }$ values for free and immobilized invertase were calculated as 31.4 and $24 \mathrm{mM}^{\mathrm{min}}{ }^{-1}$, respectively indicating lower affinity by the immobilized enzyme for its substrate and lower reaction velocity. In a continuous process using packed bed column, hydrolysis percentages of 84,29 and $18 \%$ were obtained by using flow rates of $0.25,1$ and 2 $\mathrm{bv} / \mathrm{hr}$, respectively. On the contrary, the specific productivity was enhanced by increasing the flow rate in the column.
\end{abstract}

\section{INTRODUCTION}

The enzyme invertase ( $\beta$-D-fructofuranosidase, E.C. 3.2.1.26) catalyzes sucrose hydrolysis producing an equimolar mixture of glucose and fructose named inverted sugar which represents a commercially attractive product and has been extensively used in food industries due to its sweetness and liquid form. The yeast Saccharomyces cerevisiae is used in the production of this enzyme (Mazi et al., 2006; Mahmoud, 2007; Vu and Lee, 2008). Sucrose hydrolysis can be accomplished either by hydrochloric acid or by invertase with a notorious advantage for the enzymatic over the acid process in terms of energy economy, environmental safety and low formation of by-products. However, to match the low cost of the acid process, the invertase must be used in an immobilized form (Tomotani and Vitolo, 2006). The bioprocess of invert sugar production, as any other biotechnological process, is very complex due to the number of variables involved. Hence a balanced environment with optimum temperature, $\mathrm{pH}$, agitation and flow rate is necessary for a good productivity (Blanch and Clark, 1997).

The enzyme immobilization technology offers technical and economical advantages such as repetitive use, easy removal of the enzyme from the reaction medium, longer half-life of the enzyme and the ability to the adaptation in the preferred continuous processes such as packed or fluidized bed reactors, in which it is possible to use higher enzyme dosage per volume of reactor than in the soluble enzyme process (Segura-Ceniceros et al., 2006). The main advantage of a continuous process over a batch process is the stabilization of operational

Received 18/3/2009 accepted 4/6/2009 
conditions, simpler quality control and ease of automation which leads to reduce the overall production costs (Arica and Bayramoglu, 2006; Emregul et al., 2006).

In the present study, the immobilization of Saccharomyces cerevisiae invertase was achieved by entrapment within carrageenan gel beads. The catalytic performance of the immobilized enzyme at various temperatures, $\mathrm{pH}$ values, flow rates and sucrose concentrations were studied using batch and continuous processes.

\section{MATERIALS AND METHODS}

Materials: Saccharomyces cerevisiae invertase enzyme (46 units/mg) and carrageenan were purchased from Sigma Chemical Co. Sucrose was from Merck Chemical Co. All other chemicals were of analytical grade.

Immobilization procedure: Immobilization was carried out using the method of Iborra et al. (1997). Five $\mathrm{ml}$ of the enzyme solution (2500 units in citratephosphate buffer, $0.1 \mathrm{M}, \mathrm{pH}$ ) were mixed with $20 \mathrm{ml}$ of carrageenan solution $(3 \%)$ at $4{ }^{\circ} \mathrm{C}$. This solution was then dropped into a stirred cold solution of potassium chloride $(0.3 \mathrm{M})$ using a syringe with needle. The resulting beads were kept in solution for 10 minutes after which they were filtered off, washed with sterile water and stored at $4{ }^{\circ} \mathrm{C}$.

Effect of invertase concentration on specific activity and immobilization efficiency: The immobilization procedure was carried out by using variable concentrations of the enzyme ranging from 100-500 U/ml of beads, then the activity of the immobilized enzyme was measured.

Effect of temperature and pH on sucrose hydrolysis: The effect of temperature on sucrose hydrolysis by the free and immobilized invertases was investigated in the range of $30-70{ }^{\circ} \mathrm{C}$ at $\mathrm{pH}$. The dependence of sucrose hydrolysis degree upon $\mathrm{pH}$ was examined in the $\mathrm{pH}$ range of 3-7 using citrate-phosphate buffer at $45^{\circ} \mathrm{C}$.

Hydrolysis of sucrose using batch process: Sucrose solution (5\%) was prepared in citrate-phosphate buffer $(0.05 \mathrm{M}, \mathrm{pH} 5)$. Hydrolysis was carried out at $45^{\circ} \mathrm{C}$ in $100-\mathrm{ml}$ conical flasks containing $20 \mathrm{ml}$ of the solution and provided with a magnetic stirrer. Hydrolysis was initiated by the addition of 230 units of the enzyme as a solution or as carrageenan beads containing the same amount of the enzyme. After 15 minutes, samples were withdrawn and the total reducing sugars (TRS) produced were measured by spectrophotometric method using 3,5dinitrosalicylic acid reagent (Miller, 1959).

Hydrolysis of sucrose using continuous process: The experiment was carried out in a packed bed reactor. A jacketed glass column $(1.6 \times 11 \mathrm{~cm})$ was used. The carrageenan beads, containing the immobilized invertase were suspended in citratephosphate buffer solution $(0.05 \mathrm{M}, \mathrm{pH} 5)$ and poured into the column. The column temperature was controlled at $45{ }^{\circ} \mathrm{C}$ by circulating water in the jacket. Sucrose solution, of $50 \%$ concentration was fed continuously into the column at flow rates of $0.25,0.5,0.75,1.0,1.25,1.5,1.75$ and 2.0 bed volume/hour (bv/hr). After steady state had been attained, aliquot samples were collected from the outlet solution and measured for the concentration of total reducing sugars (TRS).

Hydrolysis measurement: The hydrolysis percentage was calculated using the following formula: Hydrolysis $(\%)=$ TRS/So $x 100$

TRS is the total reducing sugar (glucose + fructose) in mmole, So is the initial sucrose concentration in mmole/liter. 
Determination of Kinetic Parameters: $K_{m}$ and $V_{\max }$ values of the free and immobilized invertase were determined by Lineweaver-Burk plot using various substrate concentrations $(0.029-0.29 \mathrm{M})$ in citrate-phosphate buffer $(0.05 \mathrm{M}, \mathrm{pH} 5)$ at $45{ }^{\circ} \mathrm{C}$.

Storage stability: The free and immobilized enzymes were kept in citratephosphate buffer $(0.05 \mathrm{M}, \mathrm{pH} 5)$ at $4{ }^{\circ} \mathrm{C}$ and their activities were measured at one week intervals up to 12 weeks.

\section{RESULTS AND DISCUSSION}

Immobilization yield: The ratio of the activity of the immobilized invertase to the activity of the free invertase was found to be $88 \%$. The immobilized enzyme was active for 42 days without remarkable drop in activity. Approximately full activity was retained after 16 batch reactions.

Effect of invertase concentration on the specific activity and immobilization efficiency: Specific activity, which is defined as the total enzyme units retained per $\mathrm{ml}$ of gel beads, was increased upon increasing the amount of the added enzyme in the gel matrix (Fig. 1). The relationship did not follow the first order kinetics. Total retained activities of 88,207 and $245 \mathrm{U} / \mathrm{ml}$ were retained when the added enzyme concentrations were 100,300 and $500 \mathrm{U} / \mathrm{ml}$, respectively.

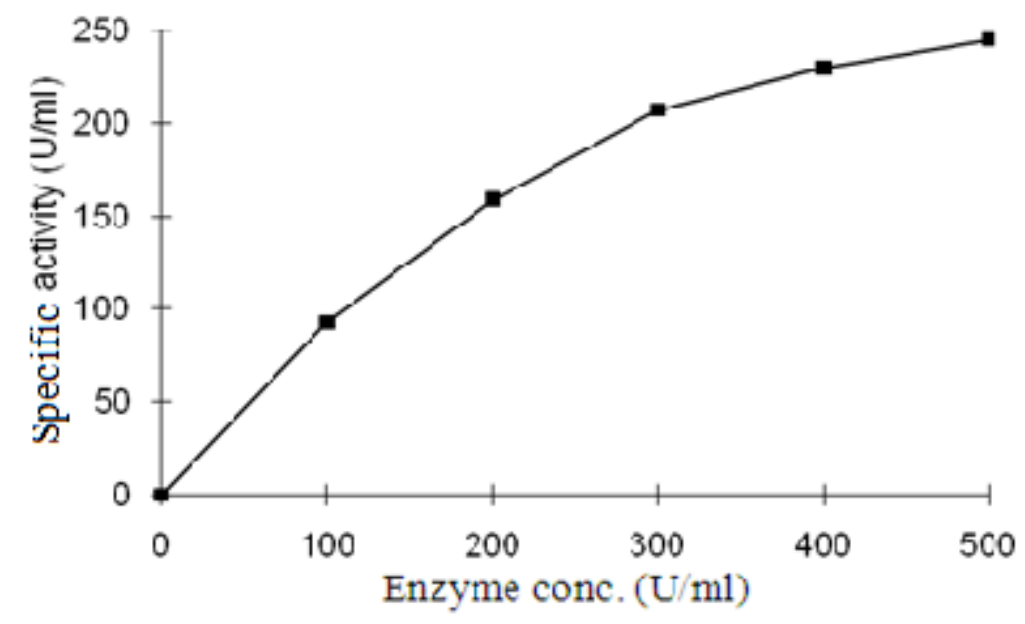

Fig. (1) : Effect of enzyme concentration on specific activity of immobilized invertase.

Another method could be used to express the relationship between the amount of the added enzyme and the retained activity by plotting the added enzyme concentration and the immobilization efficiency, which refers to the ratio of the immobilized enzyme activity to the free enzyme activity. This relationship was found to be reverse proportional (Fig. 2).

Immobilization efficiencies of 88,69 , and $49 \%$ were obtained with added enzyme concentrations of 100,300 , and $500 \mathrm{U} / 100 \mathrm{ml}$, respectively. This decrease might be caused by the diffusional restriction in bead membrane so that the activity of the immobilized enzyme was not fully utilized (Chang et al., 1998) and 
to the inhibitory effect of the hydrolysis products, glucose and fructose, when their concentrations increase inside the gel beads.

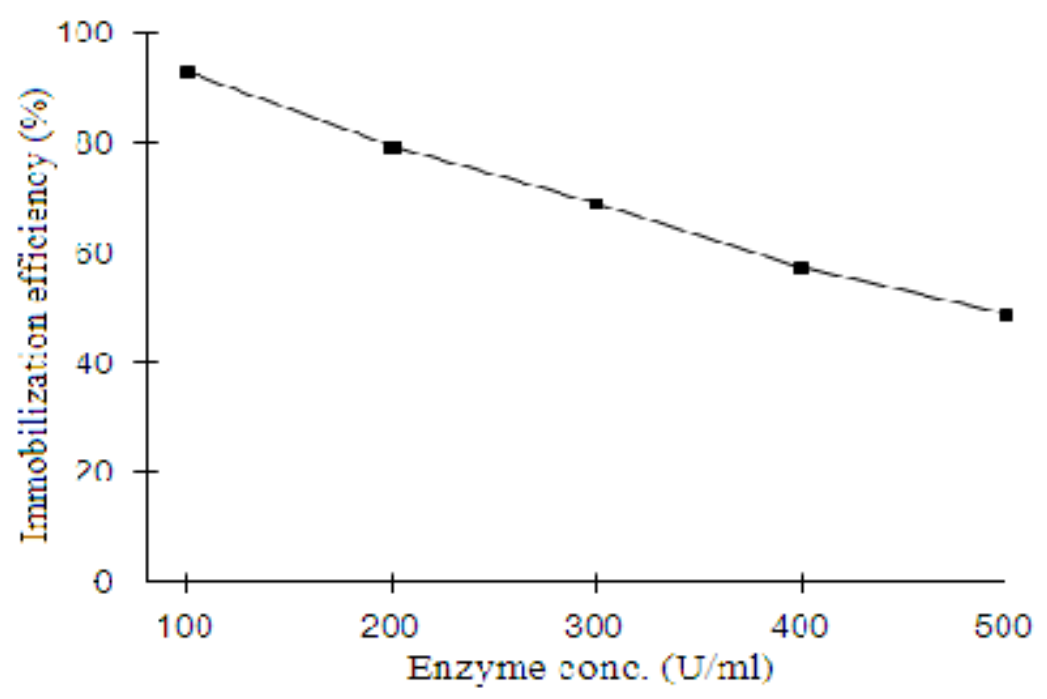

Fig. (2): Effect of enzyme concentration on Immobilization efficiency.

Storage stability: Storage stability is a prominent factor for commercialization of an enzyme. Immobilized invertase showed excellent storage stability compared to the free enzyme (Fig. 3). After 12 weeks of storage at $4{ }^{\circ} \mathrm{C}, 93 \%$ of the initial

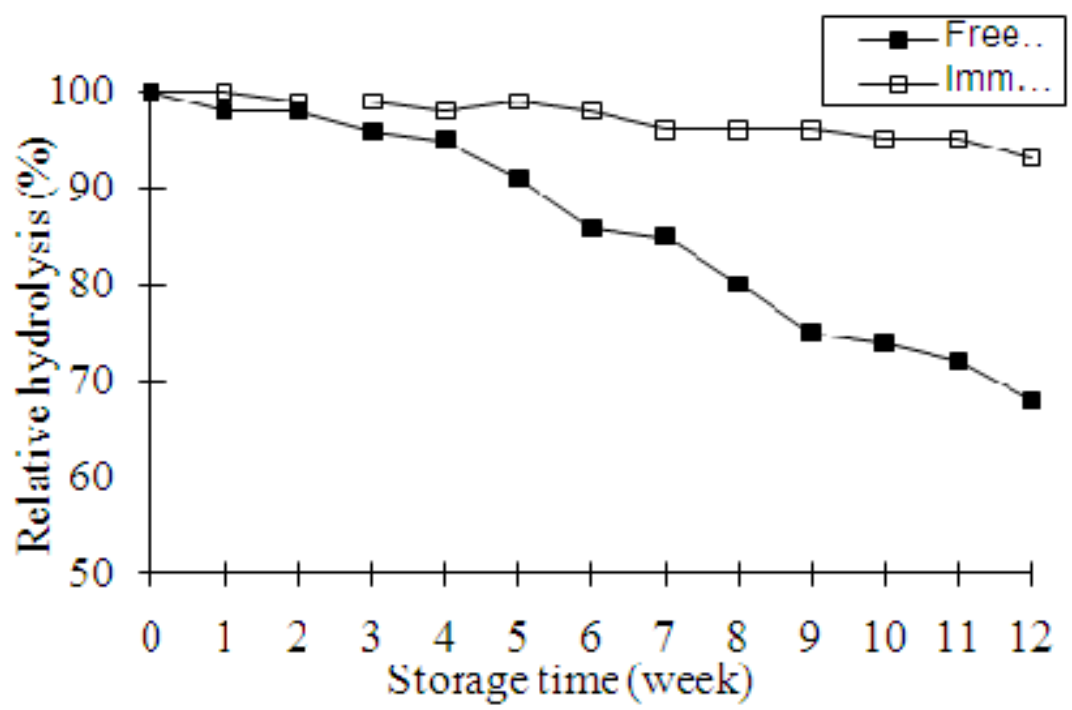

Fig. (3): Storage stability of free and immobilized invertase.

activity was retained in the immobilized enzyme. The free enzyme showed less storage stability and retained $68 \%$ of the initial activity during the same storage time period indicating a considerable enhancement of immobilization on stability. It has been argued that this higher stability of the immobilized enzyme was due to the physical protection of carrageenan gel. Approximately similar result has been 
reported by Gomez et al. (2006) for invertase immobilized on carboxymethylcellulose modified chitin.

Effect of temperature on sucrose hydrolysis: Maximum hydrolysis, for both free and immobilized forms of invertase, was achieved at $55^{\circ} \mathrm{C}$ with a good activity in the range of $40-60{ }^{\circ} \mathrm{C}$. At lower temperatures, the reaction proceeded slowly and at higher temperatures, thermal deactivation of the enzyme became faster (Fig. 4). The decrease in activity may be attributed to a dramatic change in the structure of the enzyme that hindered the availability of the active sites, with a possible denaturation of the enzyme itself (Kouassi et al., 2005). Optimum temperature did not affected by immobilization but the immobilized enzyme had a relatively wider high activity range which suggests a higher thermal stability of the immobilized invertase. The enhancement of enzyme stabilization upon immobilization may be caused by the existence of a local environment for the immobilized enzymes which is less damaging than bulk solution conditions (Bailey and Ollis, 1986). Most microbial invertases have optimum temperatures in the range of $45-60{ }^{\circ} \mathrm{C}$ (Bergamasco et al., 2000; David, 2004; Ribeiro and Vitolo, 2005). Optimum temperature is a function of the enzyme source and experimental conditions such as the substrate concentration which has a remarkable protection effect against thermal denaturation. Wiseman and Woodward (1975) had recorded optimum temperatures of Saccharomyces cerevisiae invertase at 55 and $65{ }^{\circ} \mathrm{C}$ for sucrose concentrations of 2 and $60 \%$, respectively.

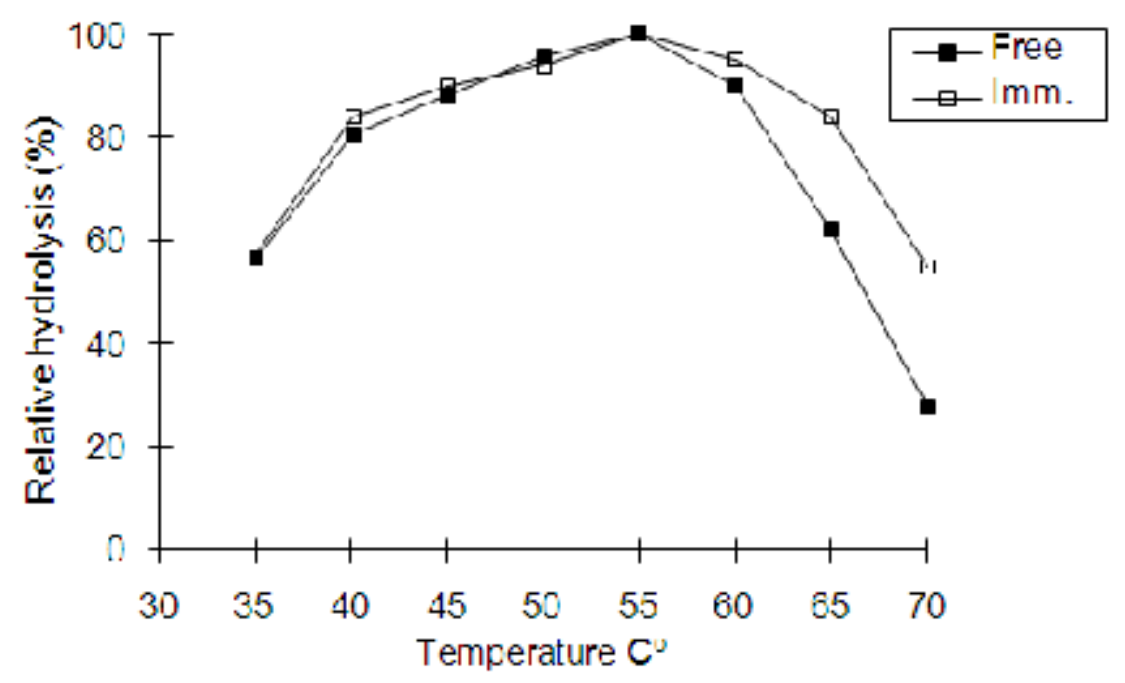

Fig. (4): Effect of temperature on sucrose hydrolysis by free and immobilized invertase from Saccharomyces cerevisiae.

Effect of pH on sucrose hydrolysis: Sucrose inversion was found to be influenced by the $\mathrm{pH}$. Optimum $\mathrm{pH}$ of the free enzyme activity was 4.5 . The immobilized enzyme showed better tolerance to the variation of solution $\mathrm{pH}$. Its optimum $\mathrm{pH}$ was in the range of 4.5-5.5 with a wider range of activity. Out of the range of 4-6, the hydrolysis rate was clearly decreased (Fig. 5).

To explain the effect of $\mathrm{pH}$ on enzymatic activity. Kang et al. (1994) stated that enzymes possess multimeric structures at different $\mathrm{pH}$ values and the ability of 


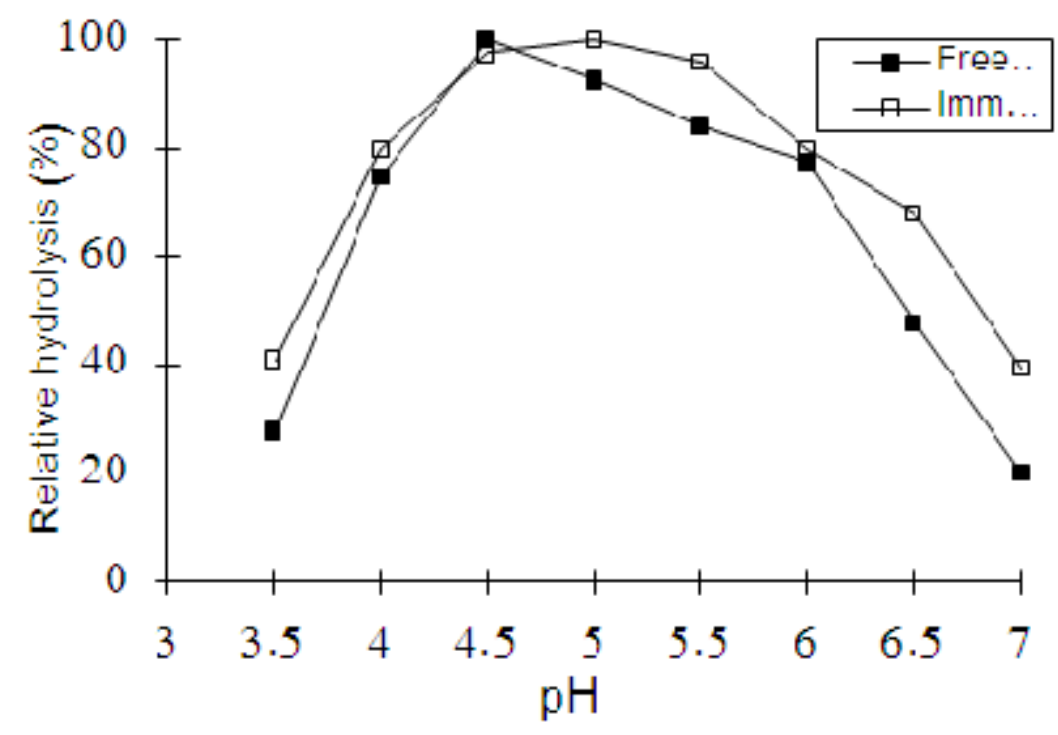

Fig. (5): Effect of $\mathrm{pH}$ on sucrose hydrolysis by free and immobilized invertase from Saccharomyces cerevisiae.

amino acids at the active sites to interact with the substrates depends on their electrostatic state. The decrease in activity at certain $\mathrm{pH}$ range shows that the enzyme faces some limitations. If the $\mathrm{pH}$ is not appropriate, the charge on one or all of the required amino acids is such that the substrate can neither bind nor react properly. The difference in the effect of $\mathrm{pH}$ on the activity between the free and immobilized forms may be resulted from the difference in the $\mathrm{pH}$ of the solution from the $\mathrm{pH}$ at the immobilized enzyme microenvironment owing to partition effects and diffusional limitations that may alter the hydrogen ion concentration in the immobilized enzyme vicinity. The same observation was reported by other investigators (Tanriseven and Dogan, 2001; Mahmoud, 2007). The main consequence of this difference is a shift in the immobilized enzyme $\mathrm{pH}$ activity profile with respect to the free enzyme (Bergamasco et al., 2000).

Kinetic parameters: The effect of substrate concentration on the free and immobilized invertase activity was studied using various concentrations of sucrose ranging from 30 to $200 \mathrm{mM}$ and plotted according to Lineweaver-Burk. As shown in the Figure 6, the $\mathrm{K}_{\mathrm{m}}$ values for the free and immobilized invertase were 63.4 and $87.8 \mathrm{mM}$, respectively. $\mathrm{V}_{\max }$ values for free and immobilized invertase were calculated as 31.4 and $24 \mathrm{mM} \cdot \mathrm{min}^{-1}$, respectively. The $\mathrm{K}_{\mathrm{m}}$ value of the immobilized enzyme was higher than that of the free invertase while $V_{\max }$ was lower. It has been found that when an enzyme is immobilized by entrapment in a gel such as carrageenan or alginate, the $K_{m}$ of the immobilized enzyme increases and the $V_{\max }$ decreases. This indicates the decreased affinity by the immobilized enzyme for its substrate and lower reaction velocity which may be due to the inhibitory effect of 


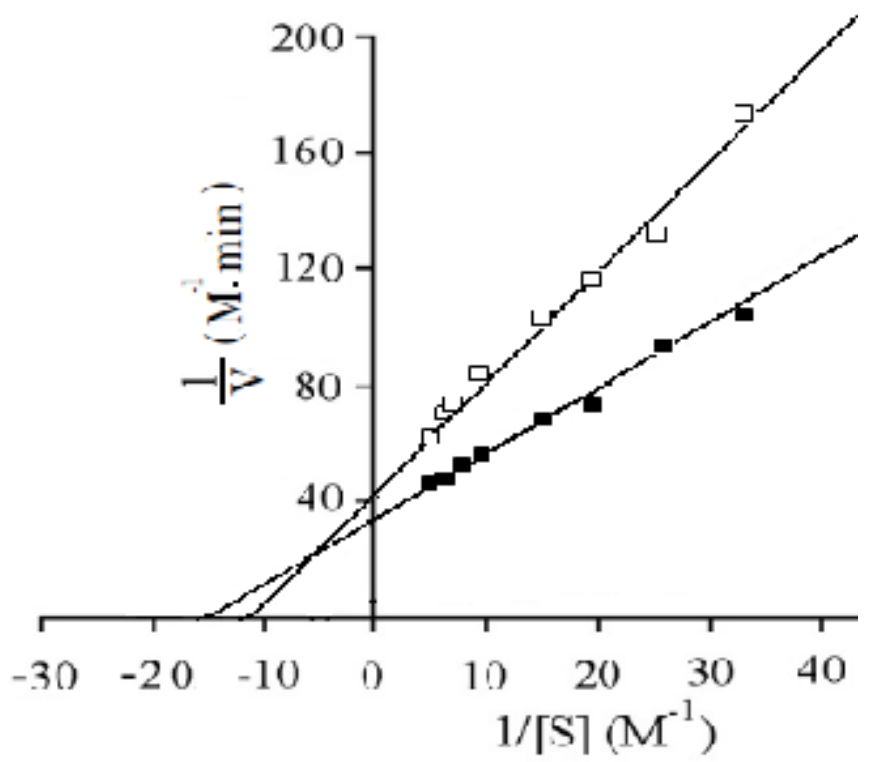

Fig. (6): Lineweaver-Burk plot of free ( $)$ and immobilized ( $~ ᄃ)$ invertase.

the hydrolysis products (glucose and fructose), the difficulty for the substrate to access the active site of the enzyme and lower transporting of the substrate and products into and out the gel beads (Akgol et al., 2001; Bayramolu et al., 2003; Vu and Lee, 2008). However, a different result was obtained by Mahmoud (2007) who used wood saw dust waste as support for immobilization.

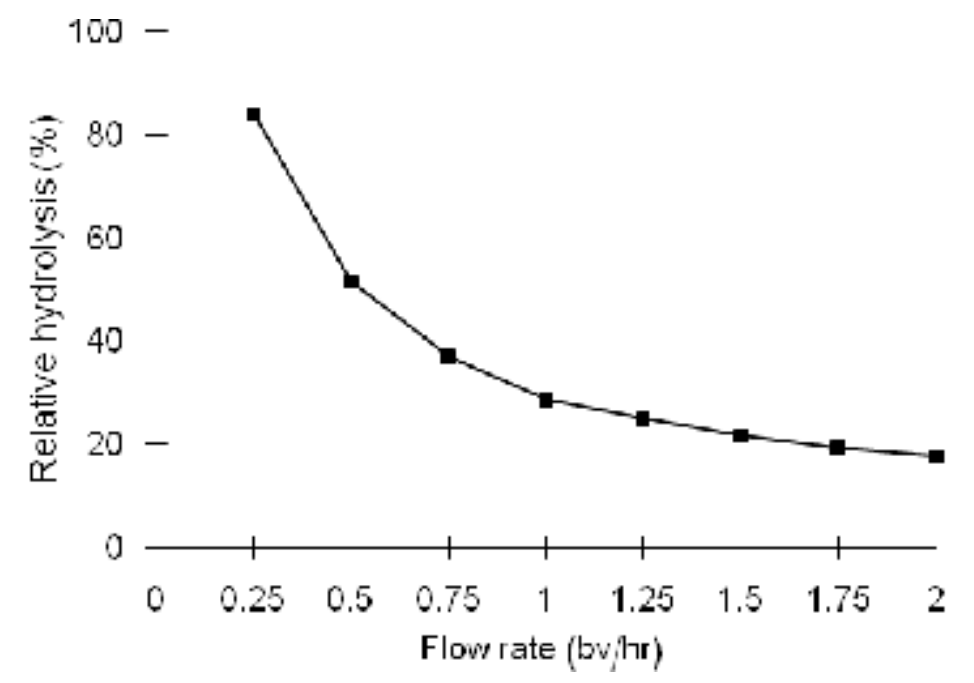

Fig. (7): Effect of flow rate on hydrolysis degree $(\mathrm{bv}=10 \mathrm{ml}$, sucrose conc. $=50 \%)$

Effect of flow rate on hydrolysis degree: A temperature-controlled glass chromatographic column was used for this purpose. As shown in the Figure 7, the conversion degree of sucrose was decreased upon increasing its flow rate throughout the column. Hydrolysis percentages of 84,29 and 18\% were obtained by using flow rates of $0.25,1$ and $2 \mathrm{bv} / \mathrm{hr}$, respectively. The hydrolysis degree diminished as the feeding rate increased because low residence time reduces the 
contact time between the enzyme and the substrate. It was noticed that the hydrolysis of relatively high concentrated sucrose solutions needs a flow rate and other reactor conditions that give a high hydrolysis rate, otherwise the residual sucrose may crystallizes and degrades syrup quality (Serna-Saldivar and RitoPalomares, 2005). In spite of achieving a high hydrolysis degree (84\%) when using a slow flow rate of the substrate throughout the column ( $0.25 \mathrm{bv} / \mathrm{hr})$, the obtained specific productivity was only 105 gm of hydrolyzed sucrose per one liter of immobilized enzyme per hour which raised to $177 \mathrm{gm} / \mathrm{l} / \mathrm{hr}$ when the hydrolysis degree was $18 \%$ which obtained by using a relatively fast flow rate (2bv/hr) (Fig. 8).

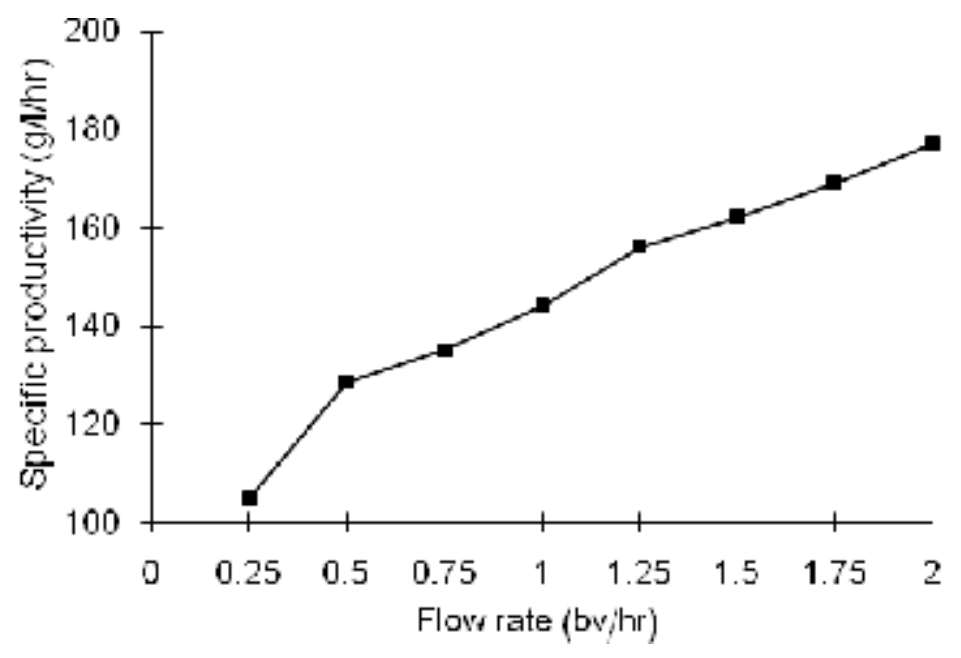

Fig. (8): Effect of flow rate on specific productivity of immobilized invertase.

This may be due to the inhibitory effect of the hydrolysis products (glucose and fructose) on the immobilized invertase upon using the slow flow rate.

تحلل السكروز باستخدام إنفرتيز خميرة Saccharomyces cerevisiae المقيد

$$
\begin{aligned}
& \text { وليد أحمد محمود } \\
& \text { قسم علوم الأغذية \كلية الزر اعة والغابات جامعة الموصل العراق }
\end{aligned}
$$

\section{الخلاصة}

تم تقييد إنزيم الإنفرتيز المنتج من خميرة Saccharomyce cerevisiae بطريقة الحجز في

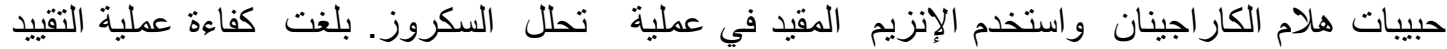

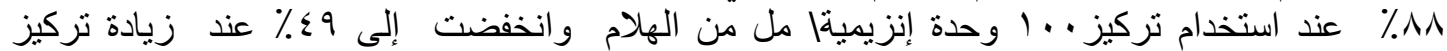

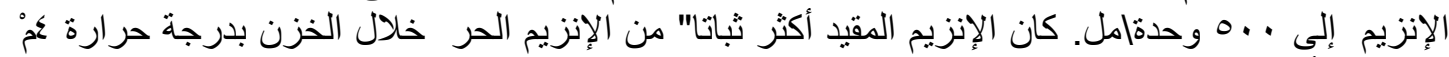

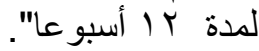
تأثرت كفاءة الإنزيم في تحلل السكروز بدرجة الحرارة وقيمة الأس الهيدروجيني. بلغت درجة الإنيا

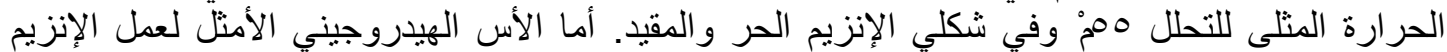

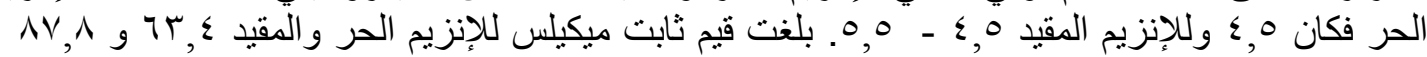

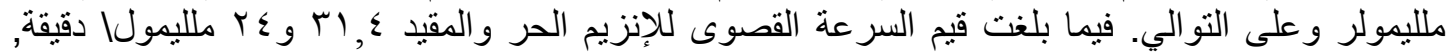

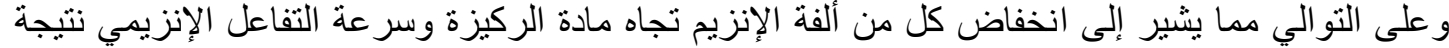

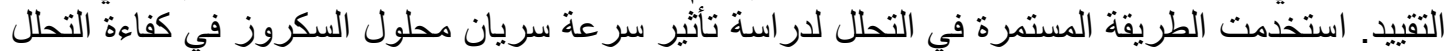

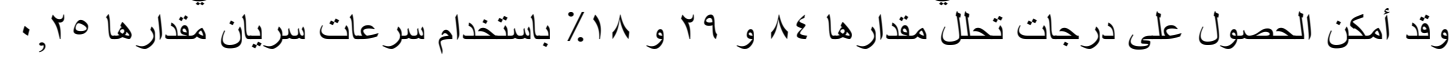


و ا و r r حجم العمودا ساعة, و على التوالي. كما ارتفعت الإنتاجية النوعية للإنزيم المقيد بزيادة سرعة سريان المادة الركيزة في العمود.

\section{REFERENCES}

Akgol, S., Y. Kaçar, A. Denizli and M.Y. Arica (2001). Hydrolysis of sucrose by invertase immobilized onto novel magnetic polyvinylalcohol microspheres. Food Chemistry, 74: 281-288.

Arica, Y. M. and G. Bayramoglu (2006). Invertase reversibly immobilized onto polyethylenimine-grafted poly(GMA-MMA) beads for sucrose hydrolysis. Journal of Molecular Catalysis, 38: 131-138.

Bailey, J.E. and D.F. Ollis (1986). Biochemical engineering fundamentals. 2nd edn., McGraw-Hill Book Company, USA.

Bayramolu, G., S. Akgol, A. Bulut, A. Denizli and A.M. Yakup (2003). Covalent immobilization of inverase onto a reactive film composed of 2- hydroxyethyl methacrylate and glycidyl methacrylate: Properties and application in a continuous flow system. Biochemical Engineering Journal, 14: 117-126.

Bergamasco, R., F.J. Bassetti, F.F. Moraes and G.M. Zanin (2000). Characterization of free and immobilized invertase regarding activity and energy of activation. Brazilian Journal of Chemical Engineering, 17: 873-880.

Blanch, H. W. and D. S. Clark (1997), Biochemical Engineering. 1st ed., Marcel Dekker, New York.

Chang, H. N., G. H. Seong, I. K. Yoo, J. K. Park and J. H. Seo (1998). Method for immobilization of whole microbial cells in calcium alginate capsules. US Patent 5766907.

David, A. E. (2004). Immobilization of enzymes on nanoporous silica composites. Ph.D. Dissertation.

Emregul, E., S. Sungur and U. Akbulut (2006). Polyacrylamide-gelatine carrier system used for invertase immobilization. Food Chemistry, 97: 591-597.

Gomez, L., H.L. Ramirez and R. Villalonga (2006). Immobilization of chitosaninvertase neoglycoconjugate on carboxymethylcellulose-modified chitin. Preparative Biochemistry and Biotechnology, 36(3): 259-271.

Iborra, J. L., A. Manjon and M. Canovas (1997). Immobilization in carrageenan. In "Bickerstaff, G. F. (ed), Immobilization of enzymes and cells, pp. 53-60" Humana Press, Totowa, New Jersey.

Kang Y., A. G. Marangoni and R. Y. Yada (1994). Effect of two polar organicaqueous solvents systems on the structure-functions relationships of proteases III, papain, and trypsin. J. Food Biochem. 17: 389-405.

Kouassi, G. K., J. Irudayaraj and G. McCarty (2005). Examination of cholesterol oxidase attachment to magnetic nanoparticles. Journal of Nanobiotechnology, 3(1): $1-9$.

Mahmoud, D. A. (2007). Immobilization of invertase by a new economical method using wood sawdust waste. Australian Journal of Basic and Applied Sciences, 1(4): 364-372

Mazi, H. E., Z. Emregul, M. Rzaev and G. Kibarer (2006). Preparation and properties of invertase immobilized on a poly(maleic anhydride-hexen-1) membrane. Journal of Biomaterials Science, Polymer Edition, 17(7):821-835. 
Miller, G.L. (1959). Use of dinitrosalicylic acid reagent for determination of reducing sugar. Analytical Chemistry, 31: 426-429.

Ribeiro, R.R. and M. Vitolo (2005). Anion exchange resin as support for invertase Immobilization. Journal of Basic and Applied Pharmaceutical Sciences, 26(3) 175-179.

Segura-Ceniceros, E.P., K.R. Dabek and A.D. Ilyina (2006). Invertase immobilization on nylon- 6 activated by hydrochloric acid in the presence of glutaraldehyde as cross-linker. Becth. Моск. Уh-Та. Cep. 47(2): 143-148.

Serna-Saldivar, S. R. and M. A. Rito-Palomares (2005). Production of invert syrup from sugarcane juice using immobilized invertase. US Patent 20050084939.

Tanriseven, A. and S. Dogan (2001). Immobilization of invertase within calcium alginate gel capsules. Process Biochemistry, 36:1081-1083.

Tomotani, E. J. and M. Vitolo (2006). Method for immobilizing invertase by adsorption on Dowex anionic exchange resin. Brazilian Journal of Pharmaceutical Sciences. 42(2): 245-249.

$\mathrm{Vu}, \mathrm{T}$. K. and V. V. Lee (2008). Biochemical studies on the immobilization of the enzyme invertase (EC.3.2.1.26) in alginate gel and its kinetics. Asean Food Journal, 15(1): 73-78.

Wiseman, A. and J. Woodward (1975). Industrial Yeast Invertase Stabilization. Proc. Biochem., 10: 24-30. 